\title{
Cellular FLICE-like inhibitory protein (cFLIP) critically maintains apoptotic resistance in human lens epithelial cells
}

\author{
Jingru Huangfu' ${ }^{1,2}$, Caili Hao ${ }^{1}$, Zongbo Wei ${ }^{1}$ I. Michael Wormstone ${ }^{4}$, Hong Yan ${ }^{2,3}$ and Xingjun Fan (1)
}

\begin{abstract}
The present study aims to understand the mechanism of the lens epithelial cell's strong anti-apoptotic capacity and survival in the mature human lens that, on the one hand, maintains lens transparency over several decades, while on the other hand, increases the risk of posterior capsule opacification (PCO). Here we compared FHL124 cells and HeLa cells, spontaneously immortalized epithelial cell lines derived from the human lens and cervical cancer cells, respectively, of their resistance to TNFa-mediated cell death. TNFa plus cycloheximide (CHX) triggered almost all of HeLa cell death. FHL124 cells, however, were unaffected and able to block caspase-8 activation as well as prevent caspase-3 and PARP-1 cleavage. Interestingly, despite spontaneous NFKB and AP-1 activation and upregulation of multiple cell survival/anti-apoptotic genes in both cell types, only FHL124 cells were able to survive the TNFa challenge. After screening and comparing the cell survival genes, CFLIP was found to be highly expressed in FHL124 cells and substantially upregulated by TNFa stimulation. FHL124 cells with a mild cFLIP knockdown manifested a profound apoptotic response to TNFa stimulus similar to HeLa cells. Most importantly, we confirmed these findings in an ex vivo lens capsular bag culture system. In conclusion, our results show that cFLIP is a critical gene that is regulating lens epithelial cell survival.
\end{abstract}

\section{Introduction}

For most people, the mature human lens maintains its transparency for several decades before beginning to increase the risk of developing cataracts ${ }^{1,2}$. Lens epithelial cells (LECs) continue to proliferate and differentiate throughout life, but this rate steadily declines post early development stage $e^{3,4}$. The lens epithelium is pivotal to lens transparency by providing nutrients from the aqueous humor to the lens ${ }^{5,6}$, maintaining lens homeostasis through ion channels and transporters ${ }^{7,8}$, and protecting adjacent fibers from stress-mediated damage and aggregation, the key mechanisms of cataractogenesis ${ }^{9,10}$. Lens epithelial cells (LECs) are constantly under insults and

\footnotetext{
Correspondence: Xingjun Fan (xfan@augusta.edu)

${ }^{1}$ Department of Cellular Biology and Anatomy, Medical College of Georgia at Augusta University, Augusta, GA, USA

2Department of Ophthalmology, Chongqing Medical University, Chongqing, China

Full list of author information is available at the end of the article

Edited by B. Zhivotovsky
}

stresses, such as UV light, smoking, post-translational modifications, and stressors in the circulating aqueous humor. Several inflammatory cytokines, such as tumor necrosis factor-alpha (TNF $\alpha)$ and interleukins, are detected in the aqueous humor and are elevated under several ocular disease conditions ${ }^{11,12}$. Thereby, lens epithelial cells need to survive challenges from their surrounding environment.

Whether LECs undergo programmed cell death (apoptosis) in the mature human lens with or without cataract has gained much attention in the field. In 1995, Li et al. ${ }^{13}$ reported a stunning 4.4 to $41.8 \%$ apoptotic rate of LECs in human cataract lenses based on TUNEL staining. However, in 1998, Harocopos et al. ${ }^{9}$ showed that minimal evidence of apoptotic LECs in both healthy and cataract lenses were detected and the study also suggested that the high level of TUNEL positive stain from the Li et al. ${ }^{13}$ study was likely resulted from necrotic cell death generated during tissue processing. Several follow-up studies

\section{(c) The Author(s) 2021}

(c) (i) Open Access This article is licensed under a Creative Commons Attribution 4.0 International License, which permits use, sharing, adaptation, distribution and reproduction cc) in any medium or format, as long as you give appropriate credit to the original author(s) and the source, provide a link to the Creative Commons license, and indicate if changes were made. The images or other third party material in this article are included in the article's Creative Commons license, unless indicated otherwise in a credit line to the material. If material is not included in the article's Creative Commons license and your intended use is not permitted by statutory regulation or exceeds the permitted use, you will need to obtain permission directly from the copyright holder. To view a copy of this license, visit http://creativecommons.org/licenses/by/4.0/. 
also pointed to a minimal level of apoptosis in LECs ${ }^{14-16}$. Preservation of the lens epithelium is vital to maintain transparency, and minimizing cell loss plays an important role in this function. A loss of cells within the epithelium, through apoptosis, would compromise the system. Therefore, a relatively high threshold to apoptosis is beneficial for lens maintenance and protection against cataracts. In contrast, this intrinsic ability to survive becomes problematic following cataract surgery.

During cataract surgery, part of the anterior lens capsule is removed via capsulorhexis, followed by phacoemulsification to remove the fiber mass before intraocular lens (IOL) implantation. However, despite severe disruption to lens integrity, some residual lens epithelial cells always remain following surgery, and these LECs survive, proliferate, migrate, and differentiate. The cellular events subsequently give rise to physical changes, such as matrix wrinkling which scatters light and significantly reduces vision quality ${ }^{17}$. This post-surgical complication of cataract surgery is called posterior capsule opacification (PCO). Therefore, understanding the mechanisms that make lens epithelial cells great survivors and demonstrate a relatively high level of resistance to stress-induced apoptosis will be of great importance in understanding the basis of PCO.

In the present study, we demonstrate a distinct insensitivity of human lens epithelial cells (FHL24) to tumor necrosis factor $\alpha$ (TNF $\alpha$, a known promoter of apoptosis) apoptosis relative to HeLa cells and report that cellular FLICE-like inhibitory protein (cFLIP) is a pivotal antiapoptotic gene that is critical for lens epithelial cell survival.

\section{Results}

\section{Lens epithelial cells are resistant to TNFa-induced cell} death

We used the FHL124 lens epithelial cell line in this study. The FHL124 cell line is a spontaneously immortalized cell line derived from the human lens epithelium ${ }^{18}$. For comparison, we used the HeLa cell line, also a spontaneously immortalized epithelial cell line derived from cervical cancer tissue. To test the cell viability in response to TNFa challenges, both FHL124 and HeLa cells were cultured with $0,10,30$, and $60 \mathrm{ng} / \mathrm{ml}$ TNF $\alpha$ for up to $24 \mathrm{~h}$. As illustrated in Fig. 1A, FHL124 cells proliferated at all TNF $\alpha$ concentrations with no remarkable amounts of cell death. In contrast, at a higher concentration of TNF $\alpha(60 \mathrm{ng} / \mathrm{ml})$, HeLa cells demonstrated reduced cell viability starting at $12 \mathrm{~h}$ and significantly worsened at $24 \mathrm{~h}$ with an approximately $50 \%$ reduction compared to non-treated cells (Fig. 1B). To enhance the sensitivity of TNFo-induced cell death, we challenged cells by $30 \mathrm{ng} / \mathrm{ml}$ TNF $\alpha$ with the presence of $10 \mu \mathrm{g} / \mathrm{ml}$ cycloheximide (CHX), a protein synthesis inhibitor. As demonstrated in Fig. 1C, TNF $\alpha$ plus CHX triggered $~ 20 \%$ cell death in HeLa cells after $5 \mathrm{~h}$ stimulation, and massive cell death $(>95 \%)$ was observed after $7 \mathrm{~h}$ treatment compared to non-treated cells. Surprisingly, FHL124 cells showed a profound resistance to the stimulation. We saw no loss in cell viability after 3 to $7 \mathrm{~h}$ of treatment (Fig. 1C). Over 75 and $65 \%$ of cells were still viable even after $12 \mathrm{~h}$ and $24 \mathrm{~h}$ of stimulation, respectively. To better understand FHL124 cells' stress response mechanism, we extend TNF $\alpha$ and CHX treatment time to 12 and $24 \mathrm{~h}$ in the rest of the study.

The cell morphology displayed by phase-contrast imaging at various time points is shown in Fig. 1D-I. HeLa cells demonstrated shrunken cell bodies after $5 \mathrm{~h}$ of treatment, and number of shrunken cell bodies increased at a $7 \mathrm{~h}$ time point. In contrast, FHL124 cells manifested a normal cell morphology compared to non-treated cells at both $12 \mathrm{~h}$ and $24 \mathrm{~h}$ time points of the stimulation.

\section{Lens epithelial cells prevent programmed cell death by blocking caspases activation}

To further dissect the molecular mechanism of TNF $\alpha$-mediated cell death, we first examined the cell nuclear morphology by Hoechst 33342 staining using fluorescence microscopy. As shown in Fig. 2E-H, condensed nuclei with a super bright appearance were seen in HeLa cells at both $5 \mathrm{~h}$ and $7 \mathrm{~h}$ after TNF $\alpha$ and CHX treatment compared to non-treated cells. The condensed nuclei were shown to be from those shrunken cells after comparing the same imaging field's phase-contrast image (Fig. 2G). In contrast, as shown in Fig. 2A-D, we did not see any condensed nuclei or shrunken FHL124 cells even at the $24 \mathrm{~h}$ time point of treatment. These results indicated that the HeLa cells underwent apoptosis because the apoptotic cells are characterized by nuclear chromatin packaging into "apoptotic bodies" with proteins manifesting as nuclear condensation ${ }^{19}$. To further titrate the ratio of apoptosis and necrosis in TNF $\alpha$ - and CHX-mediated HeLa cell death, we stained cells with FITC-labeled annexin V and propidium iodide (PI). As shown in Fig. 2J and Fig. S1, HeLa cells had more than $60 \%$ active apoptotic cells (both annexin $\mathrm{V}$ and PI-positive, quadrant 2) after $7 \mathrm{~h}$ of TNF $\alpha$ and CHX treatment, while FHL124 cells had less than $20 \%$ active apoptotic cells after $24 \mathrm{~h}$ of TNF $\alpha$ and CHX treatment.

To further unravel the cascade of TNF $\alpha$-mediated cell apoptotic pathway in both cell lines, we examined caspase-8, capase- 9 , and caspase- 3 activations by determining their pro- and cleaved forms via immunoblot assay. As shown in Fig. 3A, activation of all caspases was clearly observed in HeLa cells at $5 \mathrm{~h}$, and profoundly exacerbated at $7 \mathrm{~h}$ after stimulation compared to non-treated cells. In contrast, no cleaved-caspases were detected in FHL124 cells for up to $24 \mathrm{~h}$ challenge (Fig. 3A). We also checked the cleavage of 

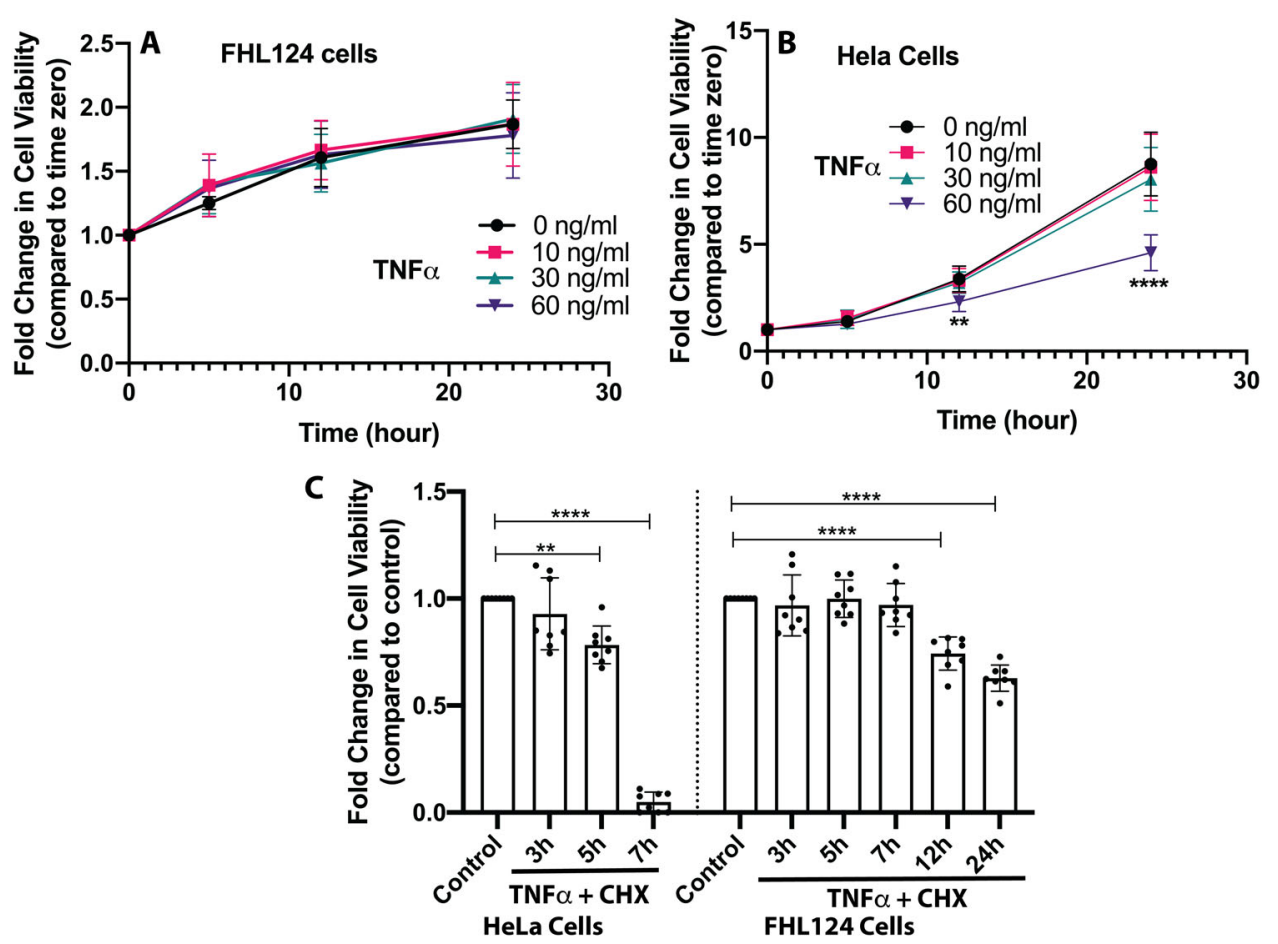

D

Control

$\mathrm{TNF} \alpha+\mathrm{CHX}$

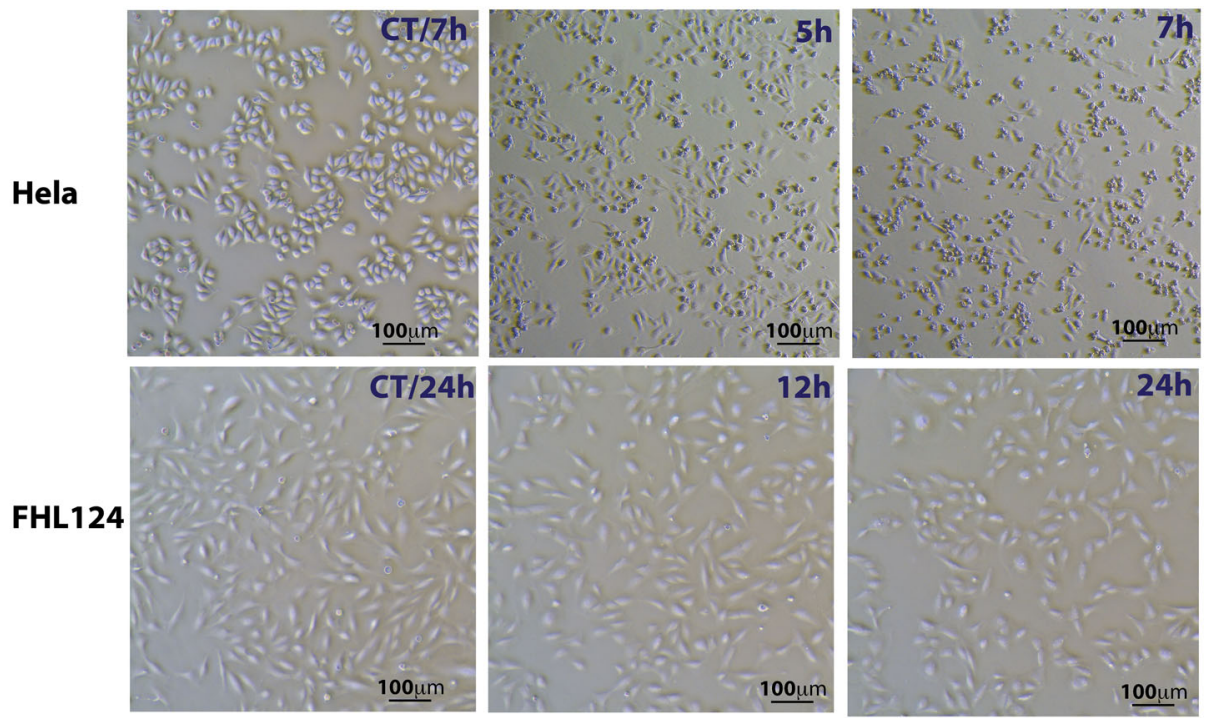

Fig. 1 FHL124 but not HeLa cells are resistant to TNFa-induced cell death. A FHL124 cells were treated by 0, 10, 30, and $60 \mathrm{ng} / \mathrm{ml} \mathrm{TNFa} \mathrm{for} \mathrm{5,} \mathrm{12,}$ and $24 \mathrm{~h}$. The cell viability was determined by CCK8 assay $(n=8)$. No cell viability loss was seen at any of the TNFa concentrations and time points. B HeLa cells were treated with the same levels of TNFa concentrations and time points. Cell viability loss was seen at $12 \mathrm{~h}$ and significantly elevated at $24 \mathrm{~h}$. C FHL124 and HeLa cells were treated with $30 \mathrm{ng} / \mathrm{ml}$ TNFa and $10 \mu \mathrm{g} / \mathrm{ml} \mathrm{CHX}$ for multiple time points from $3 \mathrm{~h}$ to $24 \mathrm{~h}$ ( $n=8$ ). Profound cell viability loss was seen in HeLa cells $7 \mathrm{~h}$ after treatment, but less than $50 \%$ cell viability loss was observed in FHL124 cells even after $24 \mathrm{~h}$ of treatment. D Cell morphology recorded by the phase-contrast imaging showed normal FHL124 cell morphology at $12 \mathrm{~h}$ and $24 \mathrm{~h}$ time point, but shrunken cell bodies of HeLa cells at $5 \mathrm{~h}$ and $7 \mathrm{~h}$ time point after TNFa and CHX treatment compared to non-treated cells. One-way ANOVA with Tukey's Honest post-hoc analysis was used to compare between groups, and only $p<0.05$ is considered significant. ${ }^{*}<0.05,{ }^{* *}<0.01,{ }^{* * *}<0.001,{ }^{* * * *}<0.0001$.

poly (ADP-ribose) polymerase-1 (PARP-1), a DNA repair enzyme, often inactivated by caspase-mediated cleavage during apoptosis ${ }^{20,21}$. As shown in Fig. 3B, PARP-1 cleavage was detected at all three time points in only HeLa cells after TNF $\alpha$ and CHX treatment but was not detectable in FHL124 cells after 24 h stimulation. 


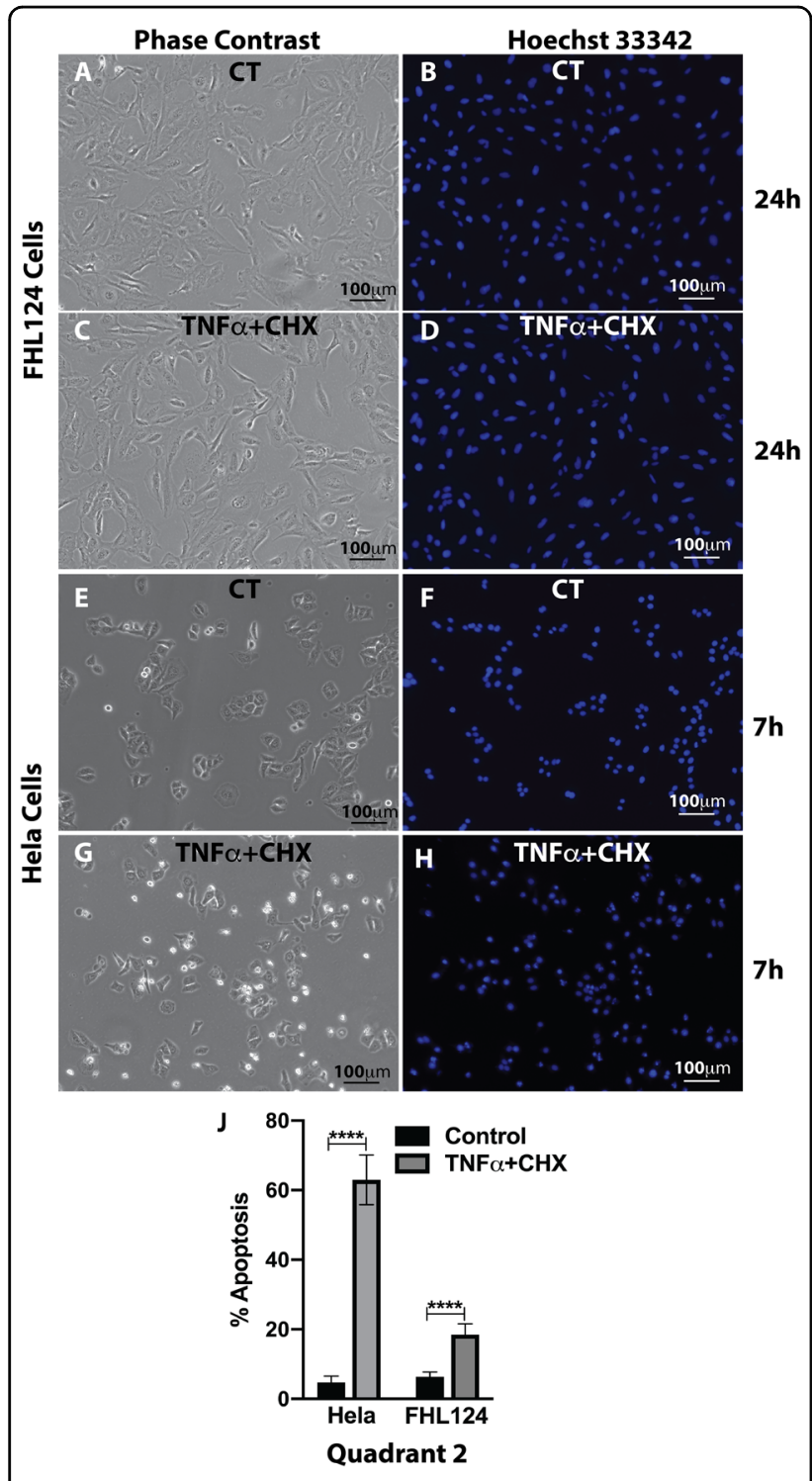

Fig. 2 TNFa induces apoptosis in HeLa cells but is resisted by FHL124 cells. A-D Cell nuclear morphology imaged via Hoechst 33342 stain showed no remarkable changes in FHL124 cells $24 \mathrm{~h}$ after TNFa and CHX stimulation. E-H Nuclear chromatin packaging into apoptotic bodies manifested as condensed nuclei with super bright appearance were seen in HeLa cells $7 \mathrm{~h}$ after treatment compared to no treated cells. J Active apoptotic cells measured by flow cytometry probed by FITC-Annexin $\mathrm{V}$ and propidium iodide (PI) demonstrated significantly increased apoptosis in HeLa cells $7 \mathrm{~h}$ after TNFa and CHX stimulation. On the contrary, less than $20 \%$ active apoptotic cells were detected $24 \mathrm{~h}$ after TNFa and CHX treatment in FHL124 cells. The Student's $t$ test was used to compare treated and no treated cells in each cell type, and only $p<0.05$ was considered significant. ${ }^{*}<0.05$, ${ }^{* *}<0.01,{ }^{* * *}<0.001,{ }^{* * * *}<0.0001$.

TNFa induces the expression of cell survival genes in both HeLa and FHL124 cells

Next, we want to understand the mechanisms that give FHL124 the leverage to maintain a robust anti-apoptotic

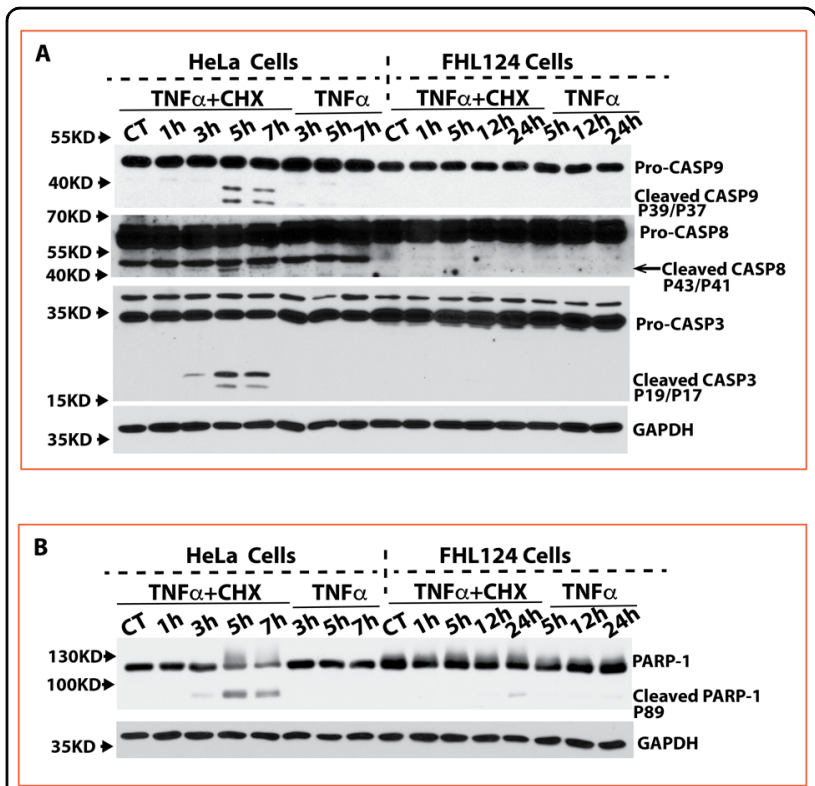

Fig. 3 FHL124 cells block caspase 8, 9, and 3 activation and PARP-1 cleavage. A Activated caspase-8, caspase-9, and caspase-3 were detected in HeLa cells starting at $3 \mathrm{~h}$ and further increased at $5 \mathrm{~h}$ and $7 \mathrm{~h}$ after TNFa and CHX stimulation. No activated caspase-8, caspase-9, and caspase- 3 were detectable in FHL124 cells spanning $24 \mathrm{~h}$ of treatment with TNFa and CHX. A higher pro-caspase-9 quantity (around 2-fold) was seen in HeLa cells than in FHL124 cells, but a higher pro-caspase-3 quantity (around 3-fold) was seen in FHL124 compared to that in HeLa cells. B Cleavage PARP-1 was detected only in HeLa cells but not in FHL124 cells after TNFa and $\mathrm{CHX}$ stimulation.

capacity over HeLa cells. Using real-time PCR, we screened over 40 genes reported to be closely associated with TNF $\alpha$ signaling (Table 1).

First, we investigated known TNF $\alpha$-mediated cell death signaling molecules, such as the death-inducing signaling complex (DISC) genes. The TNF receptor type 1 (TNFR1), the primary receptor for soluble TNF $\alpha$, did not present a noticeable change after TNF $\alpha$ and CHX treatment in either cell line (Table 1). Similar results were seen with the TNFR1-associated DEATH domain (TRADD), Fas-associated via death domain (FADD), and procaspase-8 (CASP8). We did see increased mRNA expression of several death receptors, such as TNF-related apoptosis-inducing ligand receptors 1 and 2 (TRAILR1 and TRAILR2), decoy receptor 3 (DCR3), and Fas cell surface death receptor (FAS) after TNF $\alpha$ and $\mathrm{CHX}$ stimulation. However, these death receptors' mRNA expression profiles were approximately the same between HeLa and FHL124 cells.

We did not see a remarkable difference between HeLa and FHL124 cells' endogenous pro-caspase 8 mRNA and protein levels nor a difference in their TNF $\alpha$ - and CHXinduced changes (Table 1, Fig. 3A). HeLa cells had 
Table 1 Relative mRNA expression of associated genes after TNFa and CHX stimulation.

\begin{tabular}{|c|c|c|c|c|c|c|c|c|c|}
\hline \multirow{3}{*}{$\begin{array}{l}\text { Gene name } \\
\text { Time (h) }\end{array}$} & \multicolumn{4}{|c|}{ FHL124 cells } & \multicolumn{4}{|c|}{ Hela cells } & \multirow[t]{3}{*}{ Endogenous mRNA ratio (FHL124/Hela) } \\
\hline & \multicolumn{8}{|c|}{ mRNA fold change after TNFa + CHX treatment* } & \\
\hline & $5 \mathrm{~h}$ & $7 \mathrm{~h}$ & $12 \mathrm{~h}$ & $24 \mathrm{~h}$ & $1 \mathrm{~h}$ & $3 \mathrm{~h}$ & $5 \mathrm{~h}$ & $7 \mathrm{~h}$ & \\
\hline TNF-R1 & & 0.68 & & & & & & 1.17 & $1: 1.06$ \\
\hline TRADD & & 1.05 & & & & & & 0.91 & $1.45: 1$ \\
\hline FADD & 1.03 & & 0.88 & 0.96 & 1.09 & 0.86 & 0.87 & & $1: 1$ \\
\hline TRAF1 & 147.38 & & 65.76 & 16.78 & 5.52 & 127.91 & 236.73 & & $5.56: 1$ \\
\hline TRAF2 & & 2.42 & & & & & & 4.10 & $1.06: 1$ \\
\hline TRAF5 & & 0.83 & & & & & & 0.47 & $1: 2.94$ \\
\hline TRAF6 & 2.17 & & 2.01 & 2.60 & 0.77 & 1.70 & 2.50 & & $2.78: 1$ \\
\hline DCR3 & 5.39 & & 3.53 & 4.37 & 6.64 & 2.87 & 2.77 & & $3.45: 1$ \\
\hline RIPK1 & & nd & & & & & & nd & \\
\hline RIPK3 & & 1.09 & & & & & & nd & \\
\hline FAS/CD95 & & 2.20 & & & & & & 1.16 & $1: 4.78$ \\
\hline TRAILR1 & 2.50 & & 5.88 & 13.63 & 1.39 & 1.25 & 1.61 & & $1: 4.83$ \\
\hline TRAILR2 & 6.94 & & 5.80 & 6.07 & 2.01 & 6.93 & 8.68 & & 1.79:1 \\
\hline NFKB1 & & 11.13 & & & & & & 10.17 & $1: 1.14$ \\
\hline XIAP & & 1.71 & & & & & & 2.23 & $1.32: 1$ \\
\hline CFLIP & 6.32 & & 2.94 & 1.65 & 1.44 & 1.94 & 2.7 & & $5.88: 1$ \\
\hline BCL2L1 & 1.15 & & 1.38 & 1.34 & 2.43 & 0.94 & 1.08 & & $1.22: 1$ \\
\hline BCL2A1 & 19.90 & & 4.36 & 0.99 & 3.90 & 10.14 & 11.30 & & $58.5: 1$ \\
\hline CIAP1 & 6.36 & & 3.85 & 2.05 & 5.20 & 7.23 & 9.93 & & $1.72: 1$ \\
\hline CIAP2 & 35.41 & & 21.25 & 17.52 & 2.72 & 15.69 & 24.08 & & $1: 3.32$ \\
\hline Survivin & & 1.15 & & & & & & 1.69 & $2.78: 1$ \\
\hline cJUN & 7.40 & & 2.16 & 1.54 & 49.01 & 76.63 & 34.88 & & 4.3:1 \\
\hline cFOS & 276.81 & & 143.46 & 51.77 & 59.63 & 56.72 & 34.14 & & $1: 14.51$ \\
\hline FosB & 66.24 & & 15.85 & 11.37 & 171.67 & 220.99 & 104.44 & & $1.96: 1$ \\
\hline FRA1 & 2.77 & & 0.91 & 0.82 & 3.74 & 5.99 & 6.54 & & $2.13: 1$ \\
\hline JunB & 15.23 & & 4.56 & 1.74 & 15.39 & 29.04 & 17.14 & & $1: 1.46$ \\
\hline ATF2 & & 1.54 & & & & & & 1.05 & $1: 1.06$ \\
\hline ATF3 & 40.14 & & 11.10 & 11.20 & 102.30 & 230.03 & 216.73 & & $1.04: 1$ \\
\hline CMYC & 3.89 & & 1.10 & 0.63 & 0.85 & 1.77 & 2.98 & & $1: 3.87$ \\
\hline SRC & & & & & & & & & $1: 1.55$ \\
\hline CAPN2 & 0.84 & & 0.96 & 0.44 & 1.67 & 1.34 & 0.27 & 0.34 & $2.94: 1$ \\
\hline CAPN7 & 1.05 & & 2.24 & 2.18 & 1.36 & 1.07 & 0.86 & & $1: 1.04$ \\
\hline CAPNS1 & & 1.27 & & & & & & 0.42 & $1: 1.56$ \\
\hline CASP9 & 1.78 & & 2.75 & 3.37 & 1.95 & 3.59 & 4.04 & & $1: 2.32$ \\
\hline CASP8 & 1.18 & & 0.84 & 0.75 & 1.25 & 1.07 & 1.21 & & $1.06: 1$ \\
\hline CASP7 & 1.72 & & 3.91 & 4.61 & 1.33 & 1.08 & 1.27 & & $1.66: 1$ \\
\hline
\end{tabular}


Table 1 continued

\begin{tabular}{|c|c|c|c|c|c|c|c|c|c|}
\hline \multirow{3}{*}{$\begin{array}{l}\text { Gene name } \\
\text { Time (h) }\end{array}$} & \multicolumn{4}{|c|}{ FHL124 cells } & \multicolumn{4}{|c|}{ Hela cells } & \multirow[t]{3}{*}{ Endogenous mRNA ratio (FHL124/Hela) } \\
\hline & \multicolumn{8}{|c|}{ mRNA fold change after TNFa + CHX treatment* } & \\
\hline & $5 \mathrm{~h}$ & $7 \mathrm{~h}$ & $12 \mathrm{~h}$ & $24 \mathrm{~h}$ & $1 \mathrm{~h}$ & $3 \mathrm{~h}$ & $5 \mathrm{~h}$ & $7 \mathrm{~h}$ & \\
\hline CASP6 & 0.84 & & 1.07 & 1.58 & 1.18 & 0.94 & 0.86 & & $2.37: 1$ \\
\hline CASP3 & 2.67 & & 2.15 & 1.97 & 1.31 & 1.57 & 2.10 & & $2.32: 1$ \\
\hline CUL3 & 0.65 & & 2.01 & 2.26 & 1.12 & 0.55 & 0.61 & & 1:1.45 \\
\hline CARP1 & 0.47 & & 0.30 & 0.16 & 0.64 & 0.40 & 0.29 & & $1: 2.40$ \\
\hline CARP2 & & 2.82 & & & & & & 1.32 & $1: 2$ \\
\hline
\end{tabular}

*The standard deviation was removed due to limited space.

approximately 2-fold caspase-9 mRNA and protein levels (Table 1, Fig. 3) compared to FHL124 cells. However, no significant differences were seen in either cell types after stimulation. FHL124 had an over 2-fold higher endogenous pro-caspase-3 mRNA (Table 1) and protein (Fig. 3) expression compared to HeLa cells. These results suggest that the high levels of apoptosis resistance exhibited by FHL124 cells are not due to low caspase expression but is likely dictated by genes that regulate the fate of caspase activation.

We saw a significant upregulation of signal molecules that initiate $\mathrm{NFKB}$ and AP1 activation, such as TNF receptor-associated factors 1,2 , and 6 (TRAF1, TRAF2, TRAF6), cFOS, cJUN, FosB, FRA1, and JunB. However, we did not find major discrepancy between both cell types before and after TNF $\alpha$ and CHX stimulation (Table 1).

The robust NFKB and AP-1 activation inspired us to compare various anti-apoptotic genes associated with these two transcription factors. The mRNA expression of Survivin, X-linked inhibitor of apoptosis protein (XIAP), and Bcl-2-like protein 1 (Bclx) was modestly increased ( $<2$-fold), while expression of BCL2-related protein A1 (BCL2A1) and cellular inhibitors of apoptosis protein 1 and 2 (CIAP1, CIAP2) was significantly increased $(>2$ fold) in both cell lines after TNF $\alpha$ and CHX stimulation. However, no remarkable change was seen in protein expression in both cell lines treated by TNF $\alpha$ with or without CHX (Fig. 4A). Interestingly, TNF $\alpha$ and $\mathrm{CHX}$ treatment suppressed CIAP2 and Survivin protein expression in both HeLa and FHL124 cells compared to non-treated cells. Unfortunately, we could not verify the A1 protein expression pattern because of equivocal data obtained by commercial A1 antibodies.

cFLIP is the critical anti-apoptotic element in FHL124 cells

Cellular FLICE-like inhibitory protein (cFLIP), also known as caspase-8 and FADD-like apoptosis regulator (CFLAR), stood out as a putative candidate. First, the endogenous cFLIP mRNA expression levels in FHL124 cells were approximately 6 -fold higher than those in HeLa cells (Fig. 4C). Second, FHL124 cells had a more robust response to treatment via upregulation cFLIP mRNA expression by more than 6 -fold while only about 3 -fold upregulation was seen in HeLa cells at the $5 \mathrm{~h}$ time point (Fig. 4B). The cFLIP protein expression in HeLa and FHL124 cells with and without TNF $\alpha$ and CHX treatment was also determined by immunoblot and was found to match the mRNA expression pattern (Fig. 4D, E).

\section{A mild degree of cFLIP knocking down triggers FHL124 cells' apoptotic response to TNFa and $\mathrm{CHX}$}

Testing the notion of the critical role of cFLIP in lens epithelial cell apoptosis resistance, we first created cFLIP knockdown FHL124 cells. We screened several shRNA targets and identified two mild knocking down shRNA (KD1 and KD2). We then combined KD1 and KD2 lentiviral particles to create KD3-FHL124-cFLIP knockdown cells with around a 50\% reduction of cFLIP protein expression (Fig. 4F, G). The scrambled shRNA (SC) was used as a control.

We then tested the cell survival behavior after TNF $\alpha$ and CHX induction. The Hoechst 33342 nuclear stain is shown in Fig. 5, KD3-cFLIP-FHL124 cells demonstrated scattered apoptotic cells (shown as condensed nuclei) after $7 \mathrm{~h}$ of stimulation by the same concentration of TNFa plus CHX, and apoptotic cells were significantly increased $24 \mathrm{~h}$ after treatment. Minimal numbers of apoptotic cells were detected in SC control cells after $24 \mathrm{~h}$ of stimulation. APC-annexin V and the 7-AAD stain were used to determine active cell apoptosis via flow cytometry in cFLIP knockdown and SC FHL124 cells to avoid spectrum overlapping with eGFP introduction during lentiviral-based miR30 shRNA infection. As shown in Fig. 5G-L, mild cFLIP knocking down substantially increased apoptotic cells ( $>2$-fold) after TNF $\alpha$ and CHX stimulation compared to SC control cells. 


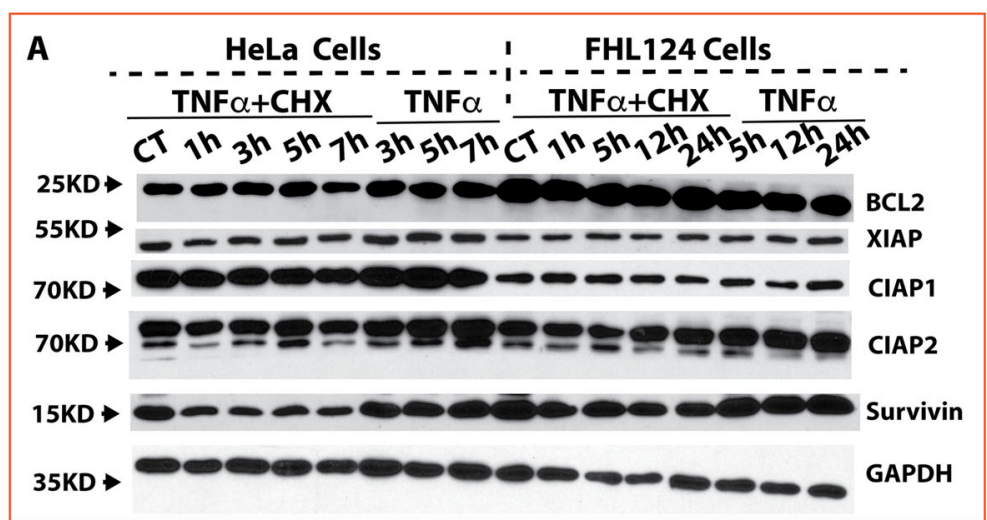

B

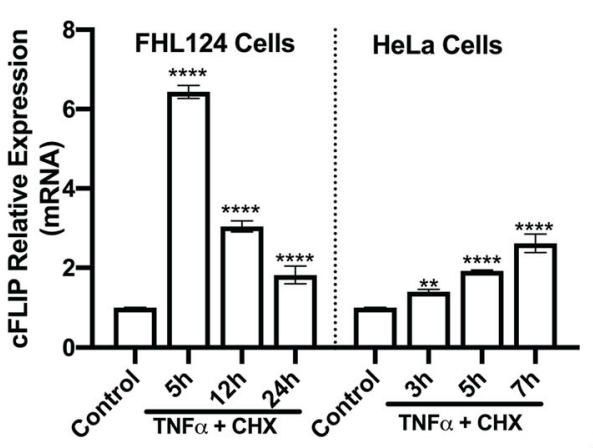

C

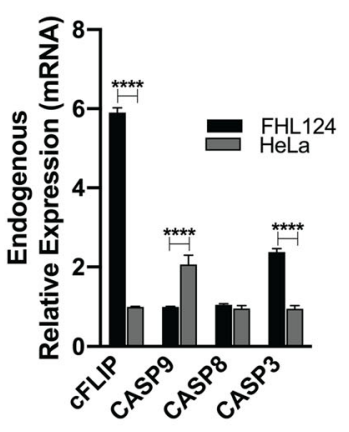

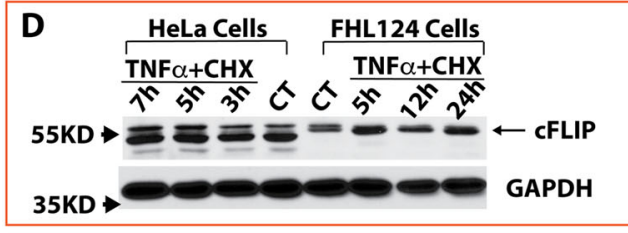

E

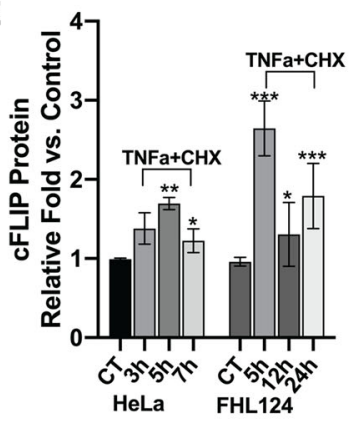

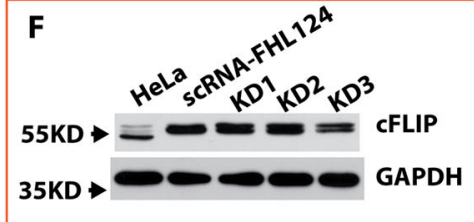

G

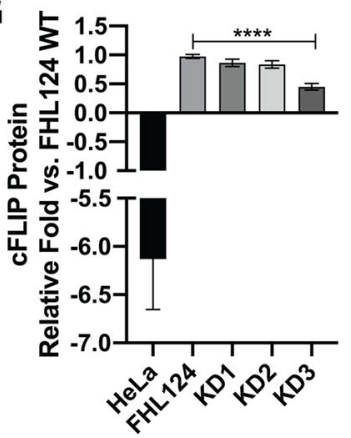

Fig. 4 cFLIP is highly expressed in FHL124 cells and also significantly upregulated after TNFa stimulation. A Anti-apoptotic protein expression in FHL124 and HeLa cell with and without TNFa and TNFa plus CHX stimulation. B Relative CFLIP mRNA expression in FHL124 and HeLa cells with and without TNFa and CHX stimulation. FHL 124 cells demonstrated a more robust response to TNFa and CHX stimulation compared to HeLa cells. C The endogenous CFLIP, Caspase-8, caspase-9, and caspase-3 mRNA levels in FHL124 cells vs. HeLa cells. A much higher cFLIP mRNA expression was seen in FHL124 cells compared to HeLa cells. D,E CFLIP protein expression after TNFa and CHX stimulation in FHL124 and HeLa cells. cFLIP protein level was increased around 3-fold in FHL124 cells at $5 \mathrm{~h}$ after TNFa and CHX stimulation, while only a mild increase was seen in HeLa cells after stimulation. F,G FHL124 cells had 6-fold endogenous cFLIP protein levels vs. HeLa cells. KD3 shRNA was able to knock down 50\% of cFLIP expression in FHL124 cells. Each assay was repeated at least three times. One-way ANOVA with Tukey's Honest post-hoc analysis was used to compare between groups, and only $p<0.05$ is considered significant. ${ }^{*}<0.05,{ }^{* *}<0.01,{ }^{* * *}<0.001,{ }^{* * * *}<0.0001$.

Immunoblot analysis also confirmed increased activation of caspase-9, caspase-8, and caspase-3 in KD3cFLIP-FHL124 cells treated by TNF $\alpha$ and CHX (Fig.
6A-D). We also found increased PARP-1 cleavage at 7, 12 , and $24 \mathrm{~h}$ after treatment compared to non-treated cells (Fig. 6A, E). 


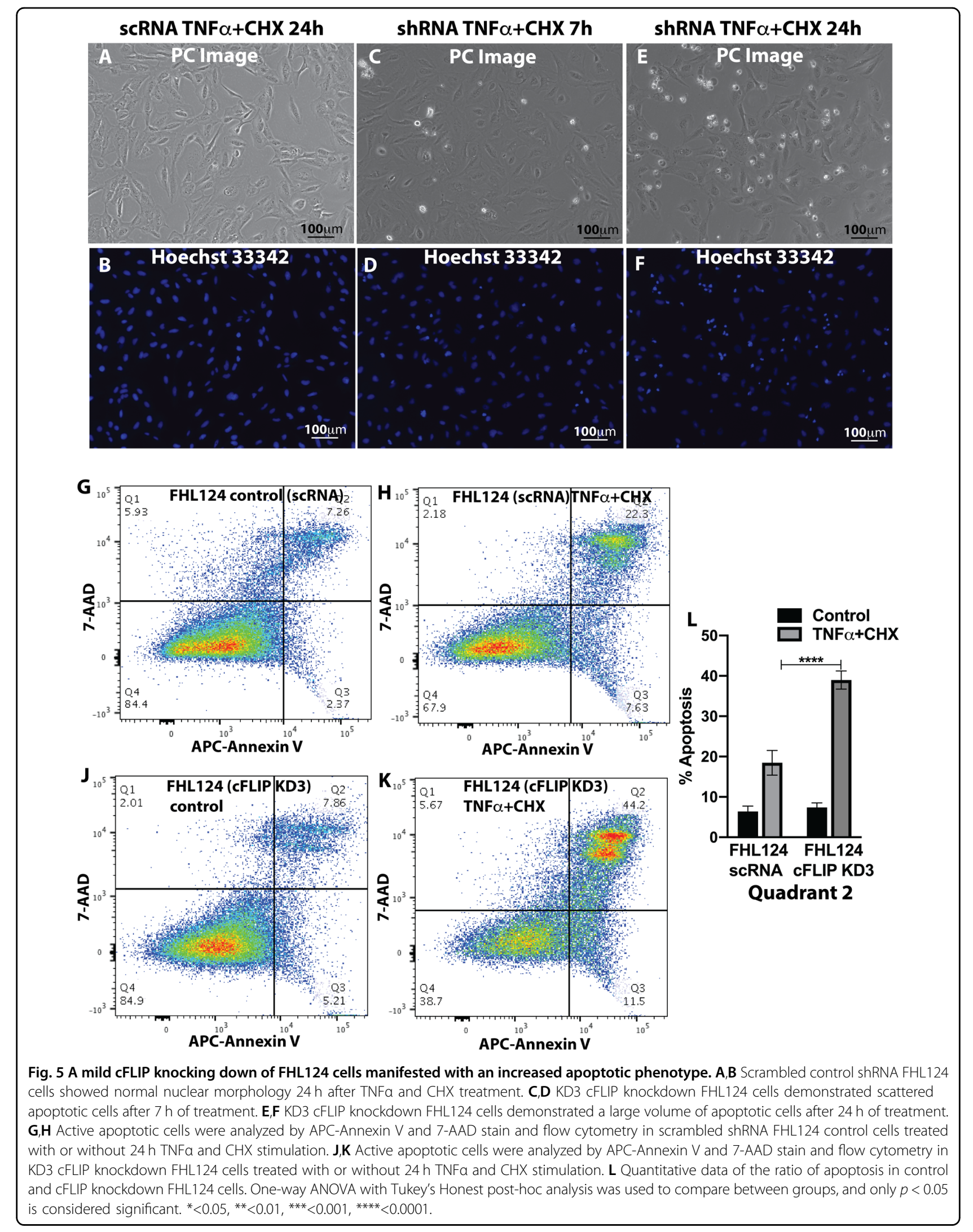




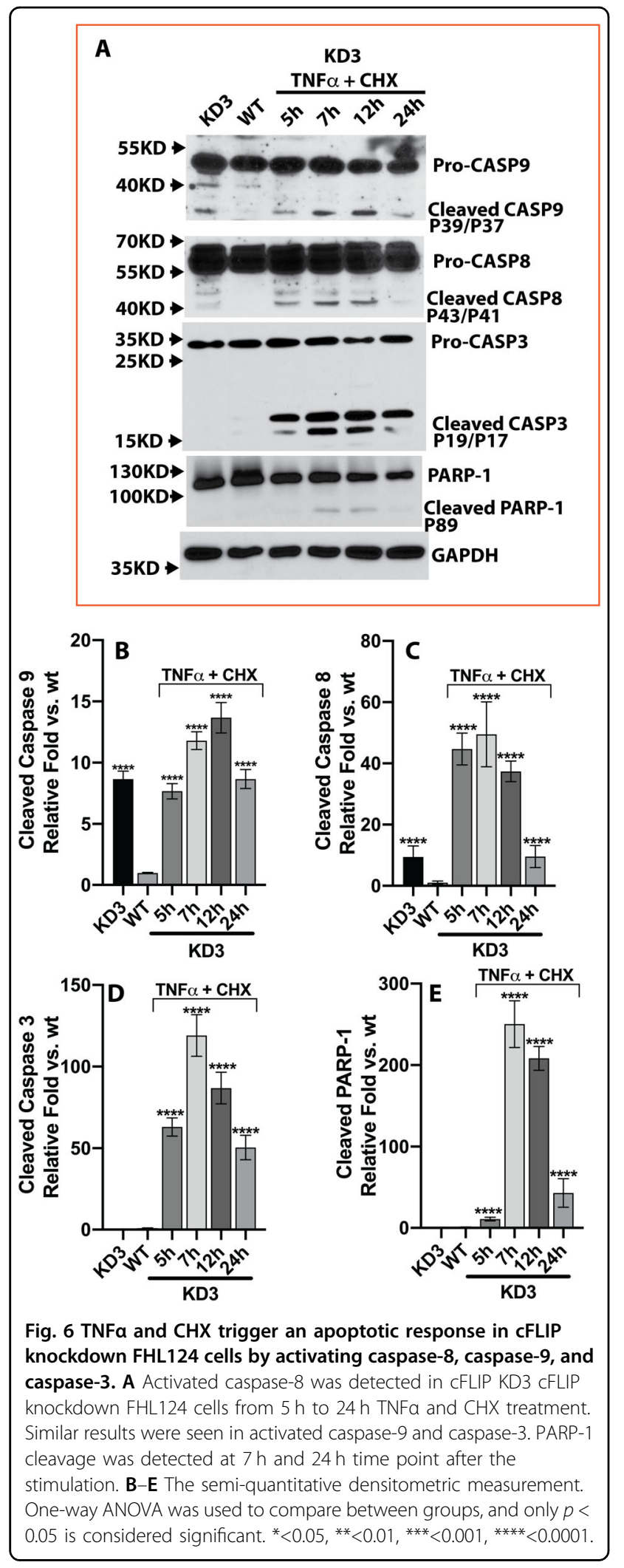

The crucial role of cFLIP in LECs' anti-apoptosis is evidenced in an ex vivo mouse lens capsular bag culture

All the strong evidence above was resulted from in vitro cell line studies, which raises the inevitable question of whether this is occurring in an in vivo situation. We decided to test the lens epithelium using mouse lens capsular bag culture, an ex vivo model that closely mimics the in vivo situation. We first examined the TNF $\alpha$ mediated cell responses in 17EM15 cells, an immortalized mouse lens epithelial cell line, to confirm whether human and mouse lens epithelial cells have similar cFLIP empowered anti-apoptotic capacities. A stable cFlip knockdown 17EM15 cell line with $\sim 50 \%$ reduction of cFLIP protein expression was established as illustrated in Fig. 7A. As shown in Fig. 7E, remarkable amount of activation of both caspase- 8 and caspase- 3 were observed in cFlip KD 17EM15 cells, while no detectable amounts of caspase- 8 and 3 activation were seen in SC cells after TNF $\alpha$ and CHX treatment. Evidently, both human and mouse lens epithelial cells are highly resistant to TNF $\alpha$ induced cell death, and cFLIP is the key anti-apoptotic gene in human and mouse LECs.

Next, we established an ex vivo lens capsular bag culture and cFlip knockdown lens epithelium model using KD1, KD2, and scrambled shRNA control lentiviral particles. As shown in Fig. 7B, despite our extensive efforts at optimizing the knocking down conditions, KD1 and KD2 could suppress around 30 and $25 \%$ of cFLIP protein expression, respectively, compared to the scrambled control (SC) virus. The low efficiency of cFLIP protein knocking down in lens capsular bags should be expected since we cannot select lens capsular bag culture by puromycin. To increase the cell death rate, we treated the lens capsular bag with a double amount of TNF $\alpha(60 \mathrm{ng} / \mathrm{ml})$ while keeping the same amount of CHX. The phase-contrast images of the lens capsular bags are shown in Fig. 8. The cuboidal shaped lens epithelial cells were observed although some regions were out of focus due to a ball-shaped capsular bag. Remarkably, the cFlip KD capsular bags demonstrated a considerable cell death at the $11 \mathrm{~h}$ time point, and massive cell death was observed $24 \mathrm{~h}$ after treatment. In contrast, no apparent cell death was observed in SC capsular bags at the $11 \mathrm{~h}$ time point, and only mild cell death was seen at the $24 \mathrm{~h}$ time point following treatment. The lens epithelium cell death in capsular bags with cFlip knocking down was also evidenced in cellular caspase- 8 and caspase- 3 activation. As shown in Fig. 7F, cleaved caspase- 8 and 3 were seen in cFlip KD capsular bags, but only weak cleaved caspase 3 bands and no cleaved caspase 8 were detected in SC capsular bags $24 \mathrm{~h}$ after TNFo and CHX treatment. 


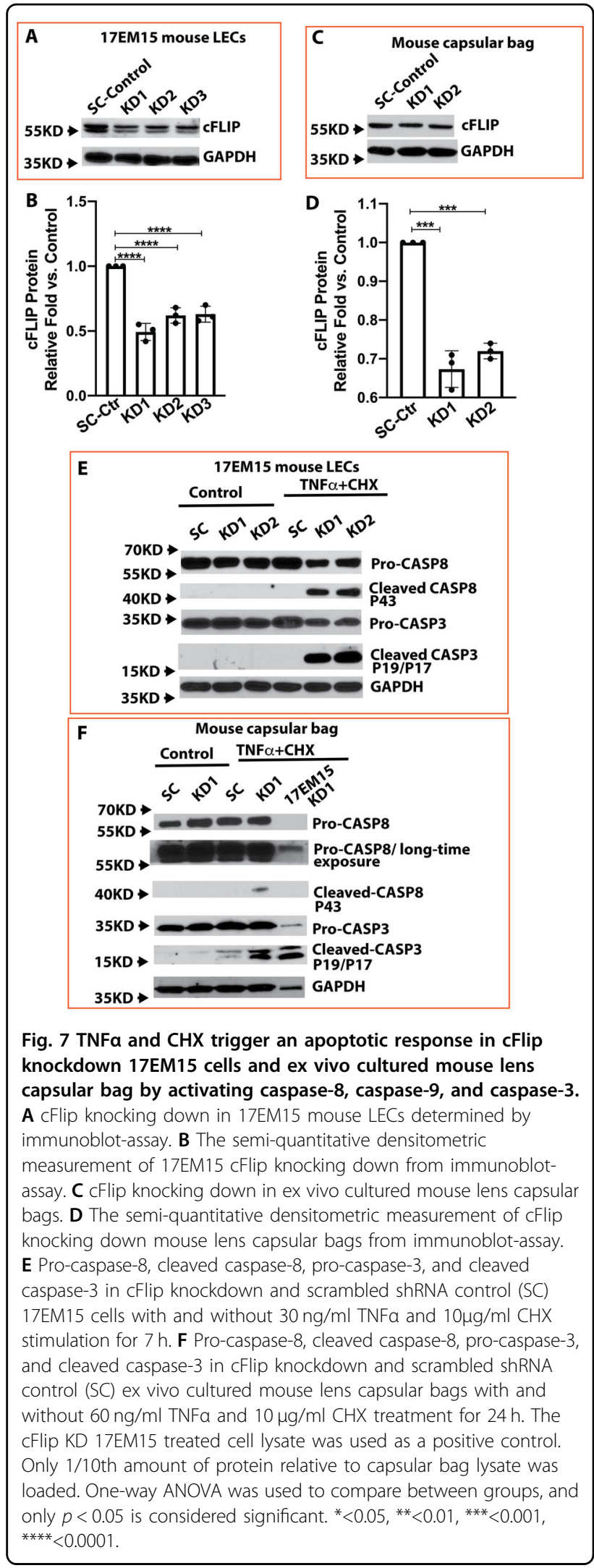

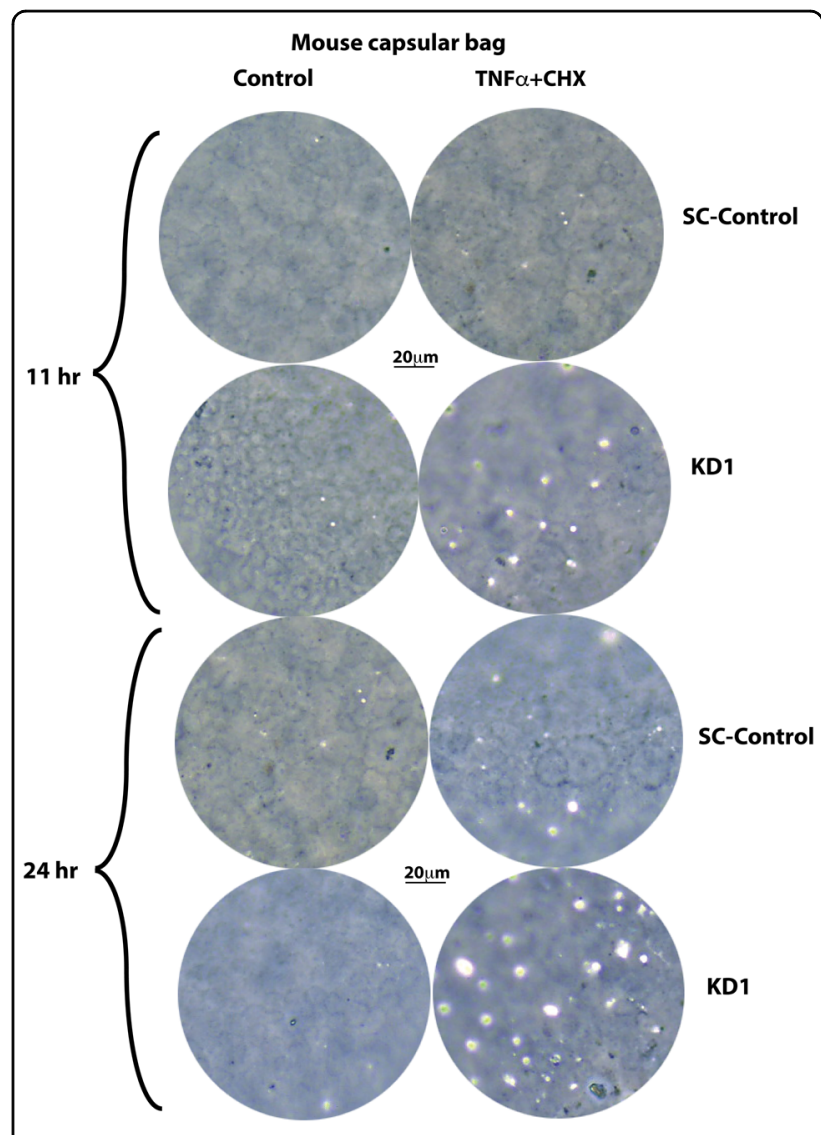

Fig. 8 Phase-contrast images of mouse lens capsular bags with and without TNFa and CHX stimulation. (Left panel) Non-treated capsular bags. (Right panel) $60 \mathrm{ng} / \mathrm{ml} \mathrm{TNFa}$ and $10 \mu \mathrm{g} / \mathrm{ml} \mathrm{CHX}$-treated capsular bags. (Upper parentheses) $11 \mathrm{~h}$ treatment with medium (control) or TNFa plus CHX. (Lower parentheses) $24 \mathrm{~h}$ treatment with medium (control) or TNFa plus CHX. 10x objective was used for image capture, and $n=6 /$ group.

\section{Discussion}

Cell fate, especially live or die, is an essential biological process that critically impacts development, tissue homeostasis, and disease ${ }^{22}$. For example, during early eye development, programmed cell death/apoptosis is required to separate the lens vesicle from the surface ectoderm $^{9,23,24}$. At the later developmental stage, during fiber cell differentiation and lens formation, apoptosis suppression is required ${ }^{25}$. A growing consensus suggests that a minimal level of apoptosis is present in healthy and cataractous human lenses despite various stresses. However, the mechanisms of the strong anti-apoptosis capability and survival rate of the lens epithelial cell in the mature human lens have not been well studied.

In the present study, we confirmed that LECs could survive TNF $\alpha$ stimulation without any cell viability loss at up to $60 \mathrm{ng} / \mathrm{ml}$ concentration for $24 \mathrm{~h}$. Multiple cell survival genes were activated following TNFa stimulation. The cellular FLICE-like inhibitory protein (cFLIP) gene 
was the critical anti-apoptotic gene with high endogenous expression and significant upregulation in the FHL124 cells compared to that in HeLa cells. The FHL124 cells with a mild cFLIP knockdown manifested with a similar apoptotic response as HeLa cells after TNF $\alpha$ and CHX stimulation. Most importantly, these findings were also explicitly confirmed by the ex vivo lens capsular bag culture system, which strongly implicated the crucial role of cFLIP in lens epithelial cell survival. Our present study also suggests that different cell types may have distinct regulatory mechanisms in cell survival.

$\mathrm{TNF} \alpha$, a proinflammatory cytokine, induces the cellular immune response and regulates cell apoptosis and necrosis via the "extrinsic" mediated programmed cell death pathway. TNF $\alpha$, through interactions with its receptors, such as TNFR1, recruits several adaptor proteins, such as FADD and TRADD ${ }^{26}$. These adaptor proteins will form a death-inducing signal complex (DISC) by recruiting and subsequently activating caspase- 8 . The activated caspase-8 can either directly trigger cell apoptosis by activating caspase-3, or via BID cleavage, activate the intrinsic apoptotic pathway through first activating caspase- 9 and then caspase- $3^{27}$. We found very similar endogenous TNFR1, FADD, and TRADD mRNA expression and their responses to TNF $\alpha$ stimulation between FHL124 and HeLa cells, which implicates that both cell types have similar signaling initiation by TNF $\alpha$. Moreover, we saw relatively similar caspase- 8 expressions in both mRNA and protein levels within HeLa and FHL124 cells. Interestingly, studies have also found that retinal pigment epithelial cells (RPEs) are resistant to TNF $\alpha$-induced cell death ${ }^{28,29}$. A later study by Yang P. et $\mathrm{al}^{30}$ concluded that a very low endogenous caspase- 8 expression is a key underlying mechanism in RPEs' resistance to TNF $\alpha$-induced apoptosis. In fact, in the same study, a significantly higher level relative to RPEs ( 30fold) of caspase-8 expression in both mRNA and protein were found in LECs ${ }^{30}$. This suggests that an entirely different mechanism is responsible for LECs' resistance to TNF $\alpha$-mediated cell death. Furthermore, FHL124 cells have a much higher pro-caspase- 3 expression as compared to HeLa cells. Thus, to protect FHL124 cells from apoptosis, tight regulation of initiator caspases activation, i.e., caspase- 8 and 9 , is required.

Intriguingly, the cFLIP protein stood out as a critical anti-apoptotic gene in the FHL124 cell response to TNF $\alpha$ mediated cell death. The cFLIP protein is a pro-caspase- 8 protein, and two major cFLIP isoforms are often seen intracellularly originating from mRNA splicing, a $26 \mathrm{KD}$ short-form (cFLIPs) and a 55KD long-form ( cFLIP $\left._{\mathrm{L}}\right)$. $\mathrm{cFLIP}_{\mathrm{L}}$ is closely reminiscent of pro-caspase 8 but lacking caspase activity. Growing evidence demonstrates that FADD and pro-caspase 8 can recruit cFLIP $_{\mathrm{L}}$ into DISC so that heterodimerization between pro-caspase- 8 and

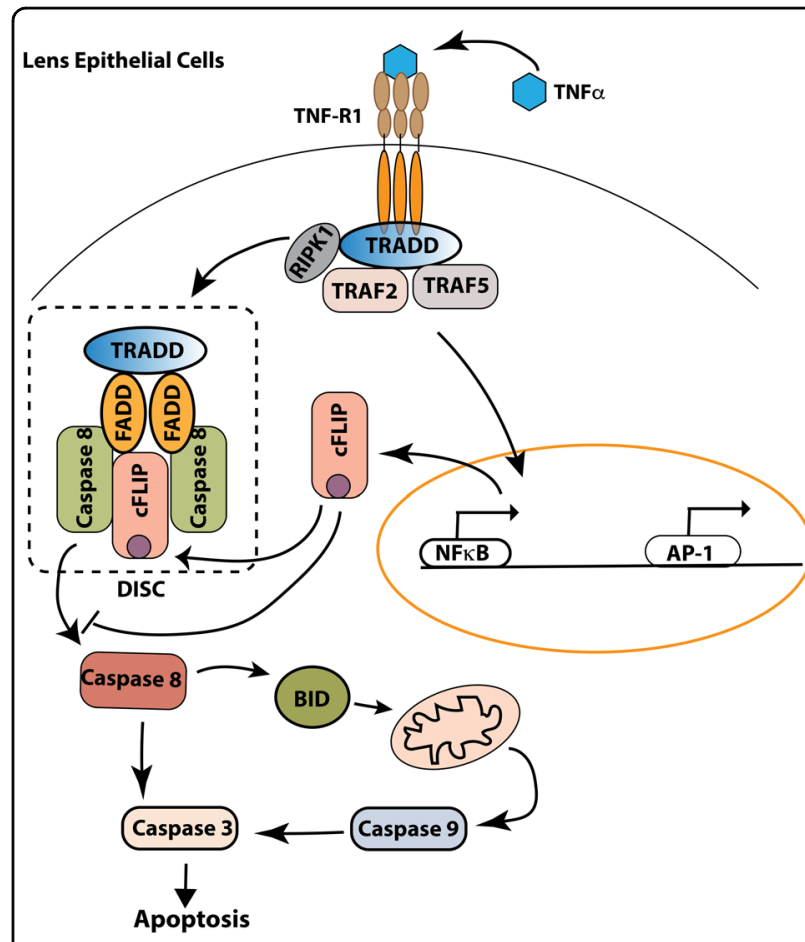

Fig. 9 A model of cFLIP-mediated LEC's survival. A proposed model is highlighting CFLIP regulation of lens epithelial cells' survival and anti-apoptotic function.

cFLIP $_{\mathrm{L}}$ replaces pro-caspase-8 homodimerization ${ }^{31-33}$. The CFLIP $_{\mathrm{L}}$ incorporation and pro-caspase-8 homodimerization disruption blocks caspase- 8 activation ${ }^{32,34}$. In the present study, the cFLIP antibody could only pick up $55 \mathrm{KD}$ isoforms $\left(\mathrm{cFLIP}_{\mathrm{L}}\right)$, and we could not exclude the possibility that short form cFLIP (cFLIPs) were also present in the FHL124 cells. However, this will not impact the LEC's strong anti-apoptotic character since both shortand long-form cFLIP can prevent caspase- 8 activation $^{35}$. Thus, as illustrated in Fig. 9, we believe that an abundant endogenous cFLIP expression and a robust upregulation upon TNFo stimulation in LECs, synthesizes a sufficient amount of cFLIP protein, which then incorporates into DISC to block caspase-8 activation and apoptotic/necrotic-based cell death. The abundant A1 expression suggests that FHL124 cells may also be resistant to intrinsic pathway-mediated apoptosis. The primary function of BCL2 family proteins in preventing apoptosis is to maintain mitochondrial membrane integrity by blocking BAX/ BAK oligomerization and apoptotic molecules' release, such as cytochrome $\mathrm{c}^{36}$. Our present study focused on the TNFo-mediated cell death pathway, an extrinsic cell death pathway. Future studies are needed to study the LEC's anti-apoptotic and survival capacity when triggered by an intrinsic pathway-mediated apoptotic mechanism.

Posterior capsule opacification (PCO) that arises from surviving residual LECs is also a testament to the lens 
epithelial cell's toughness and strong survival rate ${ }^{17}$. Previous work has shown that human lens epithelial cells residing on their natural matrix following cataract surgery on donor lenses in a laboratory setting can survive in a serum-free culture for more than 1 year ${ }^{37}$. Preventing PCO formation by either blocking LEC proliferation or inducing LEC's apoptosis has gained significant interest in the PCO research field by using cytotoxic drugs, and immunosuppressive agents, such as 5-fluorouracil (5$\mathrm{FU})^{38,39}$. Although these pharmacological interventions saw some level of restraint in PCO formation, the impact of these drugs' cytotoxicity to other ocular tissues is of a significant concern and must be carefully considered ${ }^{40}$. Our findings from this study, especially the mouse lens capsular bag culture study, suggest that even higher dosages may be required to stem LEC growth and PCO formation. More studies are needed to understand whether cFLIP is upregulated in LECs when treated by these drugs. However, by targeting the anti-apoptotic regulatory gene in LECs, such as cFLIP, we may selectively kill LECs and avoid harming other ocular tissue. For instance, RPE cells' low caspase- 8 expression would not be affected by targeting cFLIP.

In summary, the present study reveals that the cFLIP gene is playing a pivotal role in regulating lens epithelial cell survival by preventing caspase- 8 activation and subsequent programmed or necrotic cell death pathway. The LEC's strong survival rate and anti-apoptotic property may explain the mature human lens's low apoptotic phenomena in the epithelium. This discovery may also suggest cFLIP as a novel therapeutic target for PCO prevention.

\section{Materials and methods Reagents}

All chemicals used were of analytical reagent grade. Milli-Q water was used for the preparation of standards and reagents. TNF $\alpha$ (Cat. H8916), cycloheximide (CHX; Cat. C7698), and all other chemical reagents were from Sigma-Aldrich (St. Louis, MO). Hoechst 33342 (Cat. No. H3570) was ordered from ThermoFisher (Waltham, MA).

\section{Animal}

All animal experiments were performed in accordance with procedures approved by the Augusta University Animal Care and Use Committee and conformed to the Association for Research in Vision and Ophthalmology Statement for the Use of Animals in Ophthalmic and Vision Research. C57BL/6 mice were ordered from Jackson laboratory. Animals were housed under a diurnal lighting condition and allowed free access to food and water. The statistical analysis power determined the number of mice used for each assay, and mice were allocated to each experimental group randomly except for gender and age.

\section{Cell culture and treatment}

The human lens epithelial cell line of FHL124 cells ${ }^{18}$, established by Prof. John Reddan at Oakland University, were supplied by Prof. Michael Wormstone at the University of East Anglia, UK and were grown in Minimum Essential Media (MEM) with 5\% fetal bovine serum, $2 \mathrm{mmol} / \mathrm{L}$ glutamine, and $50 \mathrm{U} / \mathrm{ml}$ penicillin/ streptomycin (HyClone, Cytiva) at $35^{\circ} \mathrm{C}$ in a humidified $5 \% \mathrm{CO}_{2}$ incubator. The mouse lens epithelial cell line of 17EM15 cells were provided by Dr. Salil Lachke at the University of Delaware. 17EM15 cells, HeLa cells, and HEK293T cells were grown in Dulbecco's Modified Eagle Medium (DMEM) with 10\% fetal bovine serum, $2 \mathrm{mmol} / \mathrm{L}$ glutamine, and $50 \mathrm{U} / \mathrm{ml}$ penicillin/streptomycin (HyClone, Cytiva) at $37^{\circ} \mathrm{C}$ in a humidified $5 \%$ $\mathrm{CO}_{2}$ incubator. All used cells have been tested free of mycoplasma contamination. FHL124, 17EM15, and HeLa cells $\left(5 \times 10^{5}\right.$ cells/dish) were seeded $16 \mathrm{~h}$ before treatment in a $60 \mathrm{~mm}$ culture dish. Cells were treated by a freshly prepared full medium containing $0,10,30$, and $60 \mathrm{ng} / \mathrm{ml} \mathrm{TNF} \alpha$, an established trigger for apoptosis. Cells were harvested at $1,3,5,7,12$, and $24 \mathrm{hr}$ time points for analysis. For TNFa and CHX treatment, freshly prepared medium including $30 \mathrm{ng} / \mathrm{ml} \mathrm{TNF} \alpha$ and $10 \mu \mathrm{g} / \mathrm{ml}$ of CHX were used, and cells were then harvested at various time points as described in each assay. For the mouse lens capsular bag culture, $60 \mathrm{ng} / \mathrm{ml}$ TNF $\alpha$ and $10 \mu \mathrm{g} / \mathrm{ml} \mathrm{CHX}$ were used.

\section{Cell viability assay}

Cell viability was measured via a colorimetric assay using Cell Counting Kit-8 assay (Cat. HY-K0301, MedChem Express, Monmouth Junction, NJ) following the manufacturer's instruction. In brief, $7 \times 10^{4}$ cells per well were placed in a 96-well-plate $16 \mathrm{~h}$ before treatment. At each experimental time point, $10 \mu \mathrm{l}$ of CCK-8 solution were added to each well, and cells were incubated at $35^{\circ} \mathrm{C}$ and $37^{\circ} \mathrm{C}$ for an additional $1.5 \mathrm{~h}$ before recording the absorbance at $450 \mathrm{~nm}$. The cell-free medium served as a blank. Cell viability data for each given treatment was expressed relative to the non-treated cells.

\section{Cell apoptosis analysis by determining the nuclear morphology}

Cells were seeded in $60 \mathrm{~mm}$ culture dishes at a density of $1.8 \times 10^{5}$ cells/dish $16 \mathrm{~h}$ before treatment. To avoid apoptotic cells detaching from the culture dish during the staining and washing procedure, a low concentration $(100 \mathrm{ng} / \mathrm{ml})$ of Hoechst 33342 was added at the same time along with TNF $\alpha$ and CHX. At each time point of treatment, the phase contrast image and Hoechst 33342 stained nuclear image were captured without replacing the culture/treatment medium by an EVOS fluorescent microscope (ThermoFisher) with a 10x objective. 


\section{Cell apoptosis analysis by Annexin $\mathrm{V}$ and propidium iodide or 7-AAD stain}

Cells were seeded in $60 \mathrm{~mm}$ culture dishes at a density of $1.8 \times 10^{5}$ cells/dish $16 \mathrm{~h}$ before treatment. Since this study focused on cell apoptosis/necrosis, to avoid dead cells being washed away, the cell culture medium and PBS washing buffer were all collected and combined with trypsinized cells. Following a $5 \mathrm{~min}$ spin at $300 \mathrm{~g}$, the resulting pellet was washed once by $2 \mathrm{ml}$ of cell staining buffer (Cat. 420201, BioLegend, San Diego, CA). The cell pellet was resuspended in $100 \mu \mathrm{l}$ Annexin V binding buffer (Cat. 640930, BioLegend) and stained by either FITC-Annexin V/Propidium iodide (PI) or an APCAnnexin V/7-AAD combination for $15 \mathrm{~min}$ at room temperature in the dark before adding an additional $400 \mu \mathrm{l}$ binding buffer. The APC-Annexin V/7-AAD combination was used for cFLIP expression knockdown cells, in which eGFP was used as a probe for lentiviralbased shRNA infection. Cell apoptosis/necrosis was analyzed by CytoFLEX (Beckman Coulter) and Attune NxT (ThermoFisher) flow cytometry. All flow cytometry data were analyzed by FlowJo (version 10.7).

\section{RNA extraction and real-time PCR analysis for gene expression}

A $60 \mathrm{~mm}$ dish of cultured cells was used for RNA extraction. Cells were treated as described above. At each time point, cells were washed three times with $5 \mathrm{ml}$ ice-cold PBS, and then $1 \mathrm{ml}$ TRIzol reagent (Cat. 15596026, ThermoFisher) was added. The total RNA was extracted following the manufacturer's instructions. The RNA concentration and quality were determined by DS-11 FX + NanoDrop. Only RNA samples with UV $260 \mathrm{~nm} / 280 \mathrm{~nm}$ ratio range of $1.9-2.0$ and $\mathrm{UV} 260 \mathrm{~nm} / 230 \mathrm{~nm}$ ratio $>1.8$ were used. The total RNA was treated with DNase I (Cat. 18047019, ThermoFisher) to remove any trace of DNA being reverse transcribed to complementary DNA with an oligo(dT) random primer mix (Cat. S1330S, New England Biolabs, Ipswich, MA) and M-MuLV reverse transcriptase (Cat. M0253S, New England Biolabs). Real-time PCR was performed using the SYBR Green probe and a QuantStudio 3 Real-Time PCR system (ThermoFisher). Relative expression was calculated using the $\Delta \Delta \mathrm{Ct}$ method normalized to the housekeeping gene GAPDH. Specific primer sequences are listed in Table S1. All reactions were performed in triplicate. The minimum Information for Publication of Quantitative Real-Time PCR Experiments (MIQE) guidelines $^{41}$ were followed for all real-time PCR experiments.

\section{Ex vivo mouse lens capsular bag culture}

3-month-old mice were used in this experiment. To prepare the mouse lens capsule bag culture, the mouse lens was dissected, and the peripheral tissue attached to the lens was removed. The lens was then washed three times with $10 \mathrm{ml}$ HBSS before being mounted half-way into 2\% ultrapure low melting agarose (Cat. 16520050, ThermoFisher) MEM mounting medium in the orientation of the posterior side face up in a $3.5 \mathrm{~cm}$ culture dish. A small nick was made at the lens capsule's posterior pore, 4 to 6 flaps were peeled from the posterior pore to the equator of the lens with small tweezers. The fiber mass was then removed by hydrodissection. The capsular bag was then gently washed twice with HBSS and cultured in MEM containing $100 \mathrm{U} / \mathrm{ml}$ of penicillin and streptomycin and $2.5 \mu \mathrm{g} / \mathrm{ml}$ amphotericin $\mathrm{B}$ at $37^{\circ} \mathrm{C}$ in a humidified $5 \% \mathrm{CO}_{2}$ incubator for $16 \mathrm{~h}$ before treatment. 6 capsular bags $(n=6)$ were used in each assay.

\section{Capturing the lens capsular bag image after treatment}

The lens capsular bag's phase-contrast image was captured by the Leica DMi1 inverted microscope equipped with a 5-megapixel color camera. The 10x objective was used for all imaging capture.

\section{shRNA-based cFLIP gene knocking down}

The shRNA was produced through a miR30-based system using the MSCV-miR30-eGFP vector ${ }^{42}$ for stable knockdown cells. The miR30 vector TM30 and lentiviral packing vectors (VSV-G, BH10 $\phi^{-} e n v^{-}$, pRev) were kindly provided by Dr. Jacek Skowronski at Case Western Reserve University. Two sets of shRNA targeting cFLIP and one set of scrambled shRNA were used for FHL124 cells. KD1: GAGATACAAGATGAAGAGCAAG, KD2: CAGAATAGACCTGAAGACAAAA, Scramble: CTCCC GTGAATTGGAATCC. Two sets of shRNA targeting cFLIP and one scrambled shRNA were used for 17EM15 and ex vivo mouse lens capsule explants. KD1: CCTCA CCTGGTTTCTGATTAT, KD2: CCAAGGAGCAAGAT CAAATAT, Scramble: CTCCCGTGAATTGGAATCC.

The miR30 shRNA lentiviral particles were produced from HEK293T cells as previously described ${ }^{43}$. FHL124 and 17EM15 cells were infected with mir30 shRNA lentivirus for $48 \mathrm{~h}$, and the stable RNAi cells were grown out of $0.2 \mu \mathrm{g} / \mathrm{ml}$ puromycin selection. For the ex vivo cultured mouse lens capsular bag, shRNA lentiviral particles were added in the culture medium for $48 \mathrm{~h}$, the medium was then removed, and the capsular bag was gently washed once with $2 \mathrm{ml}$ MEM medium before treatment. The cFLIP knockdown was validated by immunoblot analysis (described below).

\section{Protein extraction and immunoblot assay}

Cells were washed twice with ice-cold PBS and lysed by

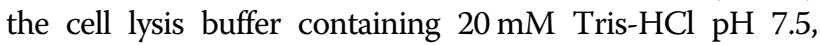
$150 \mathrm{mM} \mathrm{NaCl}, 1 \mathrm{mM} \mathrm{Na} 2$ EDTA, $1 \mathrm{mM}$ EGTA, 1\% Triton, $2.5 \mathrm{mM}$ sodium pyrophosphate, $1 \mathrm{mM} \beta$-glycerophosphate, $1 \mathrm{mM} \mathrm{Na} \mathrm{VO}_{4}, 1 \mu \mathrm{g} / \mathrm{ml}$ leupeptin, and freshly added $1 \mathrm{mM}$ PMSF. The cells were lysed on ice for $20 \mathrm{~min}$ before $10 \mathrm{~min}$ 
$15,000 \mathrm{rpm}$ centrifugation at $4{ }^{\circ} \mathrm{C}$ for $15 \mathrm{~min}$. The protein concentration in the supernatants was measured by BCA protein assay (ThermoFisher). Depending on the target protein level and antibody sensitivity, 5-20 $\mu \mathrm{g}$ protein samples were loaded and separated by SDS-PAGE. The separated proteins were then transferred to the PVDF membrane (Cat. IPVH00010, MilliporeSigma, Burlington, MA). The membrane was first blocked by $5 \%$ non-fat milk tris buffer saline plus tween 20 (PBST) for an hour at room temperature and then probed with primary antibodies of caspase-8 (Cat. 645501, Biolegend), pro-caspase 8, mousespecific (Cat. 4927, Cell Signaling, Danvers, MA), caspase- 9 (Cat. 9502, Cell Signaling), cleaved caspase 8, mouse-specific (Cat. 8592, Cell Signaling), caspase-3 (Cat. 74T2, ThermoFisher), cleaved caspase-3 (Cat. 9664, Cell Signaling), PAPR-1 (Cat. 13371-1-AP, Proteintech), cFLIP (Cat. No. 10394-1-AP, Proteintech, Rosemont, IL), cFLIP for mouse cells and tissue (AF821, R\&D System, Minneapolis, MN), Survivin (Cat. 1058-1-AP, Proteintech), CIAP1 (Cat. 666261-AP, Proteintech), CIAP2 (Cat. 24304-1-AP, Proteintech), XIAP (Cat. 10037-1-lg, Proteintech), GAPDH (Cat. PA1987, ThermoFisher) overnight at $4{ }^{\circ} \mathrm{C}$. The washed membrane was then probed with appropriate HRP-conjugated secondary antibodies (Jackson ImmunoResearch, West Grove, PA) for $1 \mathrm{~h}$ at room temperature. Immunoreactive bands were visualized using enhanced chemiluminescence (ECL) substrate (Cat. PI34580, ThermoFisher). The housekeeping gene GAPDH was used as a reference protein, and all target protein expression levels were semi-quantitatively determined by GAPDH adjustment using ImageJ software.

\section{Statistics}

All values are expressed as mean $\pm \mathrm{SD}$. In brief, the Student's $t$ test and one-way ANOVA with Tukey's Honest post-hoc analysis was computed using SPSS and GraphPad 8 software. Testing for homogeneity of variance was done using either the F-test or the Burr-Foster Q-Test, as previously described ${ }^{44}$. Significance was considered $P<0.05$.

\section{Acknowledgements}

We are very grateful to Dr. Salil Lachke at the University of Delaware for providing the mouse lens epithelial cell line. We are very grateful to Jeanene Pihkala at Augusta University Flow Cytometry Core Facility for her time and effort in cell apoptosis analysis. We are very grateful to Rachel Cui at Augusta University Cell Imaging Core for helping in microscopy image collections. We are also grateful to The Humane Research Trust (MW) in providing support to store, maintain, and distribute the FHL124 cell line. This research was supported by grants from EY028158(XF) and NEI Center Core Grant for Vision Research (P30EY031631) at Augusta University.

\footnotetext{
Author details

'Department of Cellular Biology and Anatomy, Medical College of Georgia at Augusta University, Augusta, GA, USA. ${ }^{2}$ Department of Ophthalmology, Chongqing Medical University, Chongqing, China. ${ }^{3}$ Xi'an Fourth Hospital, Affiliated Guangren Hospital School of Medicine, Xi'an Jiaotong University, Xi'an, China. ${ }^{4}$ School of Biological Sciences, University of East Anglia, Norwich, UK
}

\section{Author contributions}

X.F. conceived the research; J.H., C.H., Z.W., and X.F. acquired the data; M.W. and H.Y. contributed critical reagents; X.F. supervised the research; J.H., C.H., Z.W., and X.F. analyzed and interpreted the data; X.F. wrote the manuscript; M.W. provided assistance with editing.

\section{Ethics statement}

This research does not involve human subject.

\section{Competing interests}

J.H., C.H., Z.W., M.W., and X.F. declare they have no conflict of interest.

\section{Publisher's note}

Springer Nature remains neutral with regard to jurisdictional claims in published maps and institutional affiliations.

Supplementary information The online version contains supplementary material available at https://doi.org/10.1038/s41419-021-03683-y.

Received: 2 February 2021 Revised: 29 March 2021 Accepted: 30 March 2021

Published online: 09 April 2021

\section{References}

1. Asbell, P. A. et al. Age-related cataract. Lancet 365, 599-609 (2005).

2. Lou, M. F. Redox regulation in the lens. Prog. Retin. Eye Res. 22, 657-682 (2003).

3. Augusteyn, R. C. On the growth and internal structure of the human lens. Exp. Eye Res. 90, 643-654 (2010).

4. McAvoy, J. W., Chamberlain, C. G., de longh, R. U., Hales, A. M. \& Lovicu, F. J. Lens development. Eye 13(Pt 3b), 425-437 (1999).

5. Fan, $X$. et al. Vitamin $C$ mediates chemical aging of lens crystallins by the Maillard reaction in a humanized mouse model. Proc. Natl Acad. Sci. USA 103, 16912-16917 (2006).

6. Merriman-Smith, R., Donaldson, P. \& Kistler, J. Differential expression of facilitative glucose transporters GLUT1 and GLUT3 in the lens. Invest. Ophthalmol. Vis. Sci. 40, 3224-3230 (1999).

7. Donaldson, P., Kistler, J. \& Mathias, R. T. Molecular solutions to mammalian lens transparency. N. Physiol. Sci. 16, 118-123 (2001).

8. Kiel J. W. The Ocular Circulation, Morgan \& Claypool Publishers, (2010).

9. Harocopos, G. J., Alvares, K. M., Kolker, A. E. \& Beebe, D. C. Human age-related cataract and lens epithelial cell death. Invest. Ophthalmol. Vis. Sci. 39, 2696-2706 (1998)

10. Hightower, K. R., Reddan, J. R., McCready, J. P. \& Dziedzic, D. C. Lens epithelium: a primary target of UVB irradiation. Exp. Eye Res. 59, 557-564 (1994).

11. Kwon, J. W. \& Jee, D. Aqueous humor cytokine levels in patients with diabetic macular edema refractory to anti-VEGF treatment. PLOS One 13, e0203408 (2018).

12. Sato, T., Takeuchi, M., Karasawa, Y., Takayama, K. \& Enoki, T. Comprehensive expression patterns of inflammatory cytokines in aqueous humor of patients with neovascular age-related macular degeneration. Sci. Rep. 9, 19447 (2019).

13. Li, W. C. et al. Lens epithelial cell apoptosis appears to be a common cellular basis for non-congenital cataract development in humans and animals. J. Cell Biol. 130, 169-181 (1995).

14. Andersson, M., Honarvar, A., Sjostrand, J., Peterson, A. \& Karlsson, J. O. Decreased caspase-3 activity in human lens epithelium from posterior subcapsular cataracts. Exp. Eye Res. 76, 175-182 (2003).

15. Charakidas, A. et al. Lens epithelial apoptosis and cell proliferation in human age-related cortical cataract. Eur. J. Ophthalmol. 15, 213-220 (2005).

16. Osnes-Ringen, $\mathrm{O}$. et al. Cell death pattern in lens epithelium of cataract patients. Acta Ophthalmol. 94, 514-520 (2016).

17. Wormstone, I. M., Wormstone, Y. M., Smith, A. J. O. \& Eldred, J. A. Posterior capsule opacification: what's in the bag? Prog. Retin. Eye Res. 22, 100905. Epub ahead of print PMID: 32977000 (2020).

18. Reddan, J. R. L. C. B. et al. Generation of two non-transfected human lens cell lines. Invest. Ophthalmol. Vis. Sci. 40, S970-S970 (1999). 
19. Wyllie, A. H., Morris, R. G., Smith, A. L. \& Dunlop, D. Chromatin cleavage in apoptosis: association with condensed chromatin morphology and dependence on macromolecular synthesis. J. Pathol. 142, 67-77 (1984).

20. Soldani, C. \& Scovassi, A. I. Poly(ADP-ribose) polymerase-1 cleavage during apoptosis: an update. Apoptosis 7, 321-328 (2002).

21. Chaitanya, G. V., Steven, A. J. \& Babu, P. P. PARP-1 cleavage fragments: signatures of cell-death proteases in neurodegeneration. Cell Commun. Signal $\mathbf{8}$, 31 (2010).

22. Renehan, A. G., Booth, C. \& Potten, C. S. What is apoptosis, and why is it important? BMJ 322, 1536-1538 (2001).

23. Garcia-Porrero, J. A., Collado, J. A. \& Ojeda, J. L. Cell death during detachment of the lens rudiment from ectoderm in the chick embryo. Anat. Rec. 193, 791-804 (1979).

24. Schook, P. Morphogenetic movements during the early development of the chick eye. An ultrastructural and spatial study. C. Obliteration of the lens stalk lumen and separation of the lens vesicle from the surface ectoderm. Acta Morphol. Neerl. Scand. 18, 195-201 (1980).

25. Lang, R. A. Apoptosis in mammalian eye development: lens morphogenesis, vascular regression and immune privilege. Cell Death Differ. 4, 12-20 (1997).

26. Wajant, H., Pfizenmaier, K. \& Scheurich, P. Tumor necrosis factor signaling. Cell Death Differ. 10, 45-65 (2003).

27. Varfolomeev, E. E. \& Ashkenazi, A. Tumor necrosis factor: an apoptosis JuNKie? Cell 116, 491-497 (2004).

28. Yang, P. et al. Human RPE expression of cell survival factors. Invest. Ophthalmol. Vis. Sci. 46, 1755-1764 (2005).

29. Yang, P., McKay, B. S., Allen, J. B. \& Jaffe, G. J. Effect of NF-kappa B inhibition on TNF-alpha-induced apoptosis in human RPE cells. Invest. Ophthalmol. Vis. Sci. 45, 2438-2446 (2004).

30. Yang, P. et al. Caspase-8-mediated apoptosis in human RPE cells. Invest. Ophthalmol. Vis. Sci. 48, 3341-3349 (2007)

31. Hughes, M. A. et al. Co-operative and hierarchical binding of c-FLIP and Caspase-8: a unified model defines how c-FLIP isoforms differentially control cell fate. Mol. Cell 61, 834-849 (2016).
32. Yu, J. W., Jeffrey, P. D. \& Shi, Y. Mechanism of procaspase-8 activation by CFLIPL. Proc. Natl Acad. Sci. USA 106, 8169-8174 (2009).

33. Boatright, K. M., Deis, C., Denault, J. B., Sutherlin, D. P. \& Salvesen, G. S Activation of caspases- 8 and -10 by FLIP(L). Biochem. J. 382(Pt 2), 651-657 (2004).

34. Tummers, B. \& Green, D. R. Caspase-8: regulating life and death. Immunol. Rev. 277, 76-89 (2017).

35. Krueger, A., Schmitz, I., Baumann, S., Krammer, P. H. \& Kirchhoff, S. Cellular FLICE-inhibitory protein splice variants inhibit different steps of caspase-8 activation at the CD95 death-inducing signaling complex. J. Biol. Chem. 276 20633-20640 (2001).

36. Tzifi, F. et al. The role of BCL2 family of apoptosis regulator proteins in acute and chronic leukemias. Adv. Hematol. 2012, 524308 (2012).

37. Wormstone, I. M. et al. Human lens epithelial cell proliferation in a protein-free medium. Invest. Ophthalmol. Vis. Sci. 38, 396-404 (1997).

38. Huang, $X$. et al. Sustained release of 5-fluorouracil from chitosan nanoparticles surface modified intra ocular lens to prevent posterior capsule opacification: an in vitro and in vivo study. J. Ocul. Pharm. Ther. 29, 208-215 (2013).

39. Duncan, G., Wang, L., Neilson, G. J. \& Wormstone, I. M. Lens cell survival after exposure to stress in the closed capsular bag. Invest. Ophthalmol. Vis. Sci. 48, 2701-2707 (2007).

40. Hickey-Dwyer, M. \& Wishart, P. K. Serious corneal complication of 5-fluorouracil. Br. J. Ophthalmol. 77, 250-251 (1993).

41. Bustin, S. A. et al. The MIQE guidelines: minimum information for publication of quantitative real-time PCR experiments. Clin. Chem. 55, 611-622 (2009).

42. Fellmann, C. et al. An optimized microRNA backbone for effective single-copy RNAi. Cell Rep. 5, 1704-1713 (2013).

43. Hrecka, K. et al. HIV-1 and HIV-2 exhibit divergent interactions with HLTF and UNG2 DNA repair proteins. Proc. Natl Acad. Sci. USA 113, E3921-E3930 (2016).

44. Sell, D. R., Kleinman, N. R. \& Monnier, V. M. Longitudinal determination of skin collagen glycation and glycoxidation rates predicts early death in C57BL/ 6NNIA mice. FASEB J. 14, 145-156 (2000). 